\title{
TATA KELOLA BERKELANJUTAN BAGI BUMN BIDANG KEUANGAN NON PUBLIK
}

\author{
Oleh: \\ Mochamad Muslih \\ Email : Mochamadmuslih@stietribhakti.ac.id \\ STIE Tri Bhakti
}

\begin{abstract}
Abstrak
Tujuan penelitian ini adalah untuk mempelajari pengaruh kebijakan mengenai remunerasi dewan komisaris, remunerasi dewan direksi, dan implementasi corporate governance terhadap kinerja Badan Usaha Milik Negara (BUMN) Bidang Keuangan yang tidak terdaftar pada Bursa Efek Indonesia. Penelitian ini menggunakan metode penelitian kuantitatif. Sampel berjumlah 7 (tujuh) BUMN Bidang Keuangan yang tidak terdaftar di Bursa Efek Indonesia yaitu PT Pegadaian, Perum Peruri, PT Tugu Pratama, PT Asabri, PT Jamkrindo, PT PNM, dan PT Pengelolaan Aset. Hasil penelitian menunjukan bahwa remunerasi komisaris tidak berpengaruh signifikan pada kinerja perusahaan, remunerasi direksi tidak berpengaruh signifikan pada kinerja perusahaan, dan tata kelola perusahaan berpengaruh signifikan pada kinerja perusahaan.

Peneliti selanjutnya agar menggunakan sampel yang lebih besar pada BUMN non publik sehingga dapat diketahui dampak dari penerapan kebijakan kementerian BUMN pada Badan Usaha Milik Negara Non Publik dan menentukan kebijakan-kebijakan selanjutnya.
\end{abstract}

Key Words: Remunerasi komisaris, remunerasi direksi, corporate governance, kinerja.

\begin{abstract}
The purpose of this study was to study the effect of policies regarding the remuneration of the board of commissioners, the remuneration of the board of directors, and the implementation of corporate governance on the performance of State-Owned Enterprises (SOEs) in the Financial Sector that are not listed on the Indonesia Stock Exchange. This research uses quantitative research methods. The sample is 7 (seven) SOEs in the Financial Sector that are not listed on the Indonesia Stock Exchange, namely PT Pegadaian, Perum Peruri, PT Tugu Pratama, PT Asabri, PT Jamkrindo, PT PNM, and PT Asset Management.

The results showed that the commissioners 'remuneration had no significant effect on company performance, the directors' remuneration did not significantly influence company performance, and corporate governance had a significant effect on company performance. The next researcher is to use a larger sample of non-public SOEs so that the effects of the implementation of the SOE ministry's policies on Non-Public Enterprises can be determined and determine further policies.
\end{abstract}

Key Words: Remuneration of commissioners, remuneration of directors, corporate governance, performance. 


\section{A. Pendahuluan}

Kinerja BUMN Bidang Keuangan yang tidak terdaftar pada Bursa Efek Indonesia menunjukan kecenderungan yang cukup menggembirakan pada dekade terakhir, walaupun belum menjadi perusahaan publik. Labanya relatif meningkat setiap tahun dan masih dapat bertahan hidup hingga sekarang. Contoh BUMN Bidang Keuangan Non Publik misalnya Perum Pegadaian, PT Bahana Pembinaan Usaha Indonesia, dan PT PANN Multi Finance. Perusahaanperusahaan tersebut sampai dengan sekarang masih tetap bertahan dan menghasilkan laba yang cukup signifikan dan bahkan sebagian semakin berkembang. Berbagai faktor atau variabel dapat menjadi pemicu atau driver dari fenomena tersebut. Salah satu pendorong kinerja perusahaan adalah tingkat remunerasi komisarisnya. Komisaris sebagai organ pengarah dan pengawas atas pengelolaan yang dilakukan oleh manajemen perusahaan akan bekerja lebih giat bila remunerasinya ditingkatkan. Remunerasi direksi juga dapat menjadi salah satu pendorong kinerja perusahaan. Direksi tentunya hanya akan bertindak sesuai dengan keinginan perusahaan bila diberikan remunerasi yang cukup, sesuai dengan tugas-tugasnya. Remunerasi komisaris dan direksi BUMN diatur oleh Kementerian BUMN.

Tata kelola perusahaan juga merupakan salah satu unsur penting pendorong kinerja. Banyak penelitian yang telah membuktikan bahwa tata kelola perusahaan berpengaruh terhadap kinerja. Sejak awal tahun 2000 Pemerintah Indonesia sedang berusaha untuk membangun tata kelola pada Badan Usaha Milik Negara. Dikeluarkannya Peraturan Menteri Negara Badan Usaha Milik Negara Nomor : PER — 01 /MBU/2011 Tentang Penerapan Tata Kelola Perusahaan Yang Baik Pada Badan Usaha Milik Negara menandakan adanya komitmen pemerintah untuk menerapkan tata kelola perusahaan pada BUMN. Tata Kelola perusahaan pertama kali ditetapkan dalam Keputusan Menteri BUMN nomor Kep-117/M-MBU/2002 tentang penerapan praktek good corporate governance pada Badan Usaha Milik Negara (BUMN). Pada pasal 2 disebutkan bahwa BUMN wajib menerapkan good corporate governance secara konsisten dan atau menjadikan good corporate governance sebagai landasan operasionalnya. Berarti keputusan tersebut menghendaki agar seluruh kegiatan BUMN dan sendi-sendi perusahaan dilaksanakan berdasarkan tata kelola perusahaan yang baik. Kemudian pada pasal 2 PER - 01 /MBU/2011 di atas diatur bahwa BUMN wajib menerapkan GCG secara konsisten dan berkelanjutan dengan berpedoman pada Peraturan Menteri ini dengan tetap 
memperhatikan ketentuan, dan norma yang berlaku serta anggaran dasar BUMN. Namun belum pernah diukur atau diteliti tentang manfaat penerapan tata kelola perusahaan pada BUMN. Pengukuran yang dilakukan baru pada tingkat implementasi tata kelola perusahaan yang baik, yang dilakukan secara self-assessment oleh tim dalam perusahaan atau assessment oleh external assessor seperti Badan Pengawas Keuangan dan Pembangunan. Karena itu penelitian ini mencoba mengukur pengaruh penerapan tata kelola yang telah dibangun oleh Kementerian BUMN pada BUMN. Populasi yang diteliti adalah BUMN Bidang Keuangan Non Publik.

Terdapat berbagai penelitian terdahulu mengenai pengaruh remunerasi komisaris, remunerasi direksi, dan tata kelola perusahaan terhadap kinerja perusahaan.

Core at al (1997) menyimpulkan bahwa tidak otomatis kompensasi direktur dapat meningkatkan kinerja. Dari hasil penelitiannya Fernandes (2005) melakukan penelitian mengenai hubungan antara kompensasi direktur dengan kinerja perusahaan dengan penekanan pada peranan anggota-anggota direksi independen. Hasilnya Fernandes meragukan efektifitas sistem insentif kepada anggota dewan yang independen. Doucouliagos, Askary, dan Haman (2006) menunjukan tidak adanya hubungan yang seimbang antara remunerasi direksi dengan kinerja perusahaan. Hubungan remunerasi dengan kinerja perusahaan lebih kuat dan lebih langsung untuk remunerasi CEO daripada untuk remunerasi keseluruhan direksinya. Magnan, Onge, dan Gelinas (2009) menunjukan dari hasil penelitiannya bahwa kompensasi yang didasarkan pada ekuitas untuk para direktur menjadi penciptaan nilai dengan meningkatkan fokus pemantauan oleh direktur. Ruparelia et. al. (2016) menyimpulkan dari hasil penelitiannya bahwa kompensasi direktur meningkatkan kinerja perusahaan, walaupun tidak pada semua proxy kinerja. Kuo dan Yu (2014) menyimpulkan dari hasil penelitiannya bahwa remunerasi CEO meningkatkan kinerja perusahaan. Lindström dan Svensson (2016) menunjukan bahwa sistem insentif dari top management tidak berpengaruh signifikan pada kinerja perusahaan dan hubungan remunerasi dengan kinerja tergantung industrinya.

Gupta, Pooja, Sharma, Aarti Mehta (2016) menyatakan bahwa tata kelola perusahaan hanya memiliki sedikit pengaruh pada harga saham dan kinerja keuangannya. Al Haddad et. al (2011) telah melakukan penelitian mengenai hubungan antara corporate governance dengan indikator kinerja perusahaan-perusahaan industri di Jordan yang terdaftar pada Amman Stock Exchange (ASE). Hasil penelitian menunjukan adanya hubungan positif antara profitabilitas yang diukur dengan menggunakan EPS dan ROA dan Corporate Governance; hubungan positif antara 
likuiditas, dividen per saham, dan ukuran perusahaan dengan CG; dan hubungan positif antara CG dengan kinerja perusahaan. Todorovic (2013) menyimpulkan dari hasil penelitiannya adanya hubungan yang sangat jelas dan pengaruh implementasi prinsip-prinsip CG pada kinerja perusahaan. Pillai dan Al Malkawi (2017) meneliti dampak mekanisme internal tata kelola perusahaan (CG) pada kinerja perusahaan di negara-negara GCC. Studi ini menggunakan set panel data tingkat perusahaan dari 349 perusahaan keuangan dan non-keuangan yang terdaftar di bursa saham negara-negara GCC. Hasil penelitian menunjukkan bahwa variabel tata kelola seperti kepemilikan saham pemerintah, jenis audit, ukuran dewan, tanggung jawab sosial perusahaan dan leverage secara signifikan mempengaruhi FP di sebagian besar negara di GCC. Ararat, Black, B. Burcin (2016) menyimpulkan dari hasil penelitianya bahwa terdapat hubungan yang kuat antara tata kelola dengan nilai pasar saham perusahaan perusahaan-perusahaan public di Turki. Dengan demikian masih terdapat inkonsistensi dari hasil-hasil penelitian terdahulu.

\section{B. Tinjauan Teoritis}

Grand theory dari penelitian ini adalah teori keagenan (agency theory). Pada dasarnya agency theory mengatur tentang hubungan antara pemilik dengan manajer. Hubungan antara pemilik dan manajer harus di atur sehingga manajer akan memutuskan dan bertindak untuk kepentingan pemilik atau pemegang saham. Variabel yang dipelajari dalam penelitian ini adalah kinerja perusahaan sebagai variabel terikat, dengan variabel bebas remunerasi komisaris, remunerasi direksi, dan tata kelola perusahaan.

\section{Teori Keagenan (Agency Theory)}

Bonazzi dan Islam (2007) juga mengatakan bahwa manajer mungkin tidak selalu bertindak untuk kepentingan terbaik pemegang saham bila pengendalian atas perusahaan terpisah dari kepemilikannya. Jensen and Meckling (1976) menyatakan bahwa organisasi dipandang sebagai nexus dan set kontrak diantara faktor-faktor produksi. Penelitian ini ingin membuktikan bahwa tata kelola yang dibangun dapat berfungsi seperti yang diharapkan untuk mendorong kinerja perusahaan dan remunerasi yang diberikan kepada dewan komisaris dan dewan direksi dapat mencapai tujuannya untuk mendorong kinerja perusahaan. 


\section{Kinerja Perusahaan}

Kinerja perusahaan merupakan capaian dari target-target dalam perusahaan. Messer (2017) menyatakan bahwa membandingkan kinerja nyata dengan kegiatan yang direncanakan merupakan pengendalian manajemen yang penting. Implikasi dari pernyataan Messer tersebut adalah bahwa kinerja merupakan apa yang nyatanya telah dilakukan. Kinerja meliputi kinerja input, proses, dan output. Dincer, Hacioglu, dan Yuksel (2017) menyatakan bahwa pengukuran kinerja merupakan proses yang menganalisa output perusahaan dan efektifitas sumber daya yang diperoleh oleh perusahaan. Jadi menurut Dincer et. al kinerja meliputi output dan efektifitas dari penggunaan sumber daya. Jadi hubungan antara output dan input termasuk dalam pengukuran kinerja. Kask dan Linton (2016) membagi kinerja atas beberapa tingkatan yaitu tidak berkinerja, kinerja rendah, kinerja menengah, dan kinerja tinggi.

\section{Remunerasi Komisaris}

Komisaris mewakili pemegang saham. Tugas komisaris adalah memberikan arahan kepada perusahaan dan memantau perkembangannya. Pemberian arahan oleh komisaris diberikan melalui surat menyurat maupun dalam rapat Dewan Komisaris dengan Dewan Direksi. Menurut Undang-undang Nomor 40 tahun 2007 tugas komisaris adalah mengarahkan perusahaan dan mengawasi pelaksanannya.

Remunerasi komisaris merupakan seluruh kompensasi yang diberikan kepada ketua dan anggota dewan komisaris. Remunerasi komisaris terdiri atas kompensasi keuangan dan kompensasi natura. Contoh remunerasi komisaris misalnya gaji, tunjangan, tanciem, perumahan, olahraga, pergaulan social. Remunerasi komisaris diberikan dalam jumlah yang layak. Remunerasi Komisaris BUMN diatur dalam peraturan Kementerian BUMN. Pemberian remunerasi dalam jumlah yang layak diharapkan dapat mendorong kinerja Badan Usaha Milik Negara.

Terdapat jurnal-jurnal penelitian terdahulu mengenai pengaruh kompensasi komisaris terhadap kinerja perusahaan. Core, Holthausen, dan Larcker (1998) menyimpulkan dari hasil penelitiannya bahwa pengaruh kompensasi komisaris tergantung pada tingkat implementasi tata kelola perusahaan. Bila tata kelola perusahannya baik maka peningkatan remunerasi juga akan berpengaruh signifikan pada kinerja perusahaan. Namun tetap ada peluang bagi remunerasi untuk meningkatkan kinerja. Magnan, Onge, dan Gelinas (2009) menunjukan dari hasil 
penelitiannya bahwa kompensasi yang didasarkan pada ekuitas untuk para direktur menjadi penciptaan nilai dengan meningkatkan fokus pemantauan oleh direktur. Pengaruh tersebut akan lebih besar bila perusahaan beranjak dari kondisi tata kelola yang lemah. Ruparelia et. al. (2016) menyimpulkan dari hasil penelitiannya bahwa kompensasi direktur meningkatkan kinerja perusahaan, walaupun tidak pada semua proxy kinerja. Kuo dan Yu (2014) menyimpulkan dari hasil penelitiannya bahwa remunerasi CEO meningkatkan kinerja perusahaan.

Berdasarkan pembahasan tersebut di atas hipotesa penelitiannya adalah sebagai berikut:

\section{H1: Remunerasi Komisaris berpengaruh positif pada kinerja perusahaan.}

\section{Remunerasi Direksi}

Fernandes (2005) melakukan penelitian mengenai hubungan antara kompensasi direktur dengan kinerja perusahaan dengan penekanan pada peranan anggota-anggota direksi independen. Palmon dan Wald (2005) menyimpulkan dari hasil penelitiannya bahwa kompensasi yang tinggi akan mendorong kinerja bila terdapat implementasi tata kelola yang baik. Jadi harus ada tata kelola yang baik agar kompensasi mendorong kinerja.Hasil penelitiannya menunjukan manfaat kompensasi terhadap kinerja, namun meragukan efektifitas sistem insentif kepada anggota dewan yang independen. Magnan, Onge, dan Gelinas (2009) melakukan penelitian akademis mengenai kompensasi direktur untuk mengidentifikasi praktek-praktek yang berhubungan dengan penciptaan nilai. Hasil penelitiannya menunjukan bahwa kompensasi yang didasarkan pada ekuitas untuk para direktur menjadi penciptaan nilai dengan meningkatkan fokus pemantauan oleh direksi. Ruparelia et. al. (2016) melakukan penelitian mengenai hubungan antara remunerasi direksi dan kinerja perusahaan pada industri jasa keuangan di Kenya. Hasil penelitian menunjukan bahwa kompensasi direksi meningkatkan kinerja perusahaan. Kuo dan Yu (2014) melakukan penelitian mengenai apakah tingkat dan struktur kompensasi eksekutif berbeda berdasarkan tingkat independensi dewan. Hasilnya remunerasi CEO meningkatkan kinerja perusahaan.

Berdasarkan pembahasan tersebut di atas, hipotesa penelitiannya adalah sebagai berikut.

\section{H2 : Remunerasi Direksi berpengaruh positif pada kinerja perusahaan.}




\section{Tata Kelola Perusahaan}

Tata kelola perusahaan diterapkan pada Badan Usaha Milik Negara dengan tujuan untuk meningkatkan kinerja perusahaan. Pentingnya tata kelola perusahaan adalah untuk mengatasi masalah keagenan yang dilakukan oleh manajemen. Pemilik perusahaan dengan manajemen perusahaan mempunyai kepentingan yang berbeda. Pemilik perusahaan ingin agar perusahaannya memperoleh keuntungan setinggi mungkin. Sedangkan manajer ingin agar kompensasi yang diterimanya setinggi mungkin. Corporate governance mengatur hubungan antara keduanya sehingga tercapai goal congruence (kesesuaian tujuan). Peraturan Kementrian Negara Badan Usaha Milik Negara Nomor : PER — 01 /MBU/2011 secara implisit menyebutkan bahwa organ GCG adalah Pemegang Saham/Pemilik Modal (PS), Rapat Umum Pemegang Saham (RUPS), Dewan Komisaris/Dewan Pengawas, dan organ pendukungnya yang terdiri atas: Sekretariat Dewan Komisaris/Dewan Pengawas, Komite Audit, dan Komite Lainnya yang diperlukan, Direksi, dengan organ pendukungnya yaitu Satuan Pengawas Intern (SPI) dan Sekretaris Perusahaan.

Tata kelola perusahaan pada BUMN diatur oleh Peraturan Menteri Negara Badan Usaha Milik Negara Nomor PER — 01 /MBU/2011 tentang Penerapan Tata Kelola Perusahaan Yang Baik Pada Badan Usaha Milik Negara dan Peraturan Menteri Negara Badan Usaha Milik Negara Nomor : PER- 09 /MBU/2012 Tentang Perubahan Atas Peraturan Menteri Negara Badan Usaha Milik Negara Nomor PER-01/MBU/2011 Tentang Penerapan Tata Kelola Perusahaan Yang Baik Pada Badan Usaha Milik Negara. Untuk keperluan pengaturan implementasi GCG di BUMN Indonesia, dalam Keputusan Kementerian BUMN No. 117 tahun 2002 psl.1 disebutkan bahwa tata kelola perusahaan adalah suatu PROSES dan STRUKTUR yang digunakan oleh organ BUMN untuk meningkatkan keberhasilan usaha dan akuntabilitas perusahaan guna mewujudkan nilai pemegang saham dalam jangka panjang dengan tetap memperhatikan kepentingan stakeholders lainnya, berlandaskan peraturan perundangan dan nilai-nilai etika. Kata kunci yang harus diingat dari keputusan tersebut adalah bahwa GCG adalah struktur dan proses. Struktur itu suatu bangun yang ada pada BUMN yang terdiri atas Pemegang Saham, RUPS, Dewan Komisaris, dan Manajemen. Proses-proses yang terdapat dalam perusahaan terdapat pada berbagai manual yang disusunnya. Lebih lanjut dalam Keputusan Kementerian BUMN tersebut disebutkan bahwa BUMN wajib menerapkan good corporate governance secara konsisten dan atau menjadikan good corporate governance sebagai landasan operasionalnya. Definisi tersebut 
memberikan gambaran yang jelas tentang governance dalam suatu perusahaan. Tujuan dari governance tersebut adalah mewujudkan nilai pemegang saham.

Dalam peraturan yang lebih baru yaitu peraturan Kementrian Negara Badan Usaha Milik Negara Nomor : PER — 01 /MBU/2011 Tentang Penerapan Tata Kelola Perusahaan Yang Baik (Good Corporate Governance) pada badan usaha milik negara disebutkan bahwa GCG adalah prinsip-prinsip yang mendasari suatu proses dan mekanisme pengelolaan perusahaan berlandaskan peraturan perundang-undangan dan etika berusaha. Pengertian ini memberikan gambaran yang abstrak tentang GCG dalam suatu perusahaan. GCG merupakan serangkaian prinsip. Lebih lanjut dalam Surat Keputusan tersebut disebutkan bahwa BUMN wajib menerapkan GCG secara konsisten dan berkelanjutan dengan berpedoman pada peraturan ini dengan tetap memperhatikan ketentuan, dan norma yang berlaku serta anggaran dasar BUMN.

Assessment atau evaluasi atas tata kelola BUMN dilakukan berdasarkan Keputusan Sekretaris Kementerian Badan Usaha Milik Negara Nomor : SK - 16 /S.MBU/2012 Tentang Indikator/Parameter Penilaian dan Evaluasi Atas Penerapan Tata Kelola Perusahaan Yang Baik (Good Corporate Governance) Pada Badan Usaha Milik Negara. Pertama kali kewajiban assessment dilakukan berdasarkan pasal 44 peraturan Kementrian Negara Badan Usaha Milik Negara Nomor : PER — 01 /MBU/2011, dimana BUMN diwajibkan untuk melakukan pengukuran terhadap penerapan GCG dalam bentuk penilaian (assessment) yaitu program untuk mengidentifikasi pelaksanaan GCG di BUMN melalui pengukuran pelaksanaan dan penerapan GCG di BUMN yang dilaksanakan secara berkala setiap 2 (dua) tahun; dan evaluasi (review), yaitu program untuk mendeskripsikan tindak lanjut pelaksanaan dan penerapan GCG di BUMN yang dilakukan pada tahun berikutnya setelah dilakukan penilaian (assessment), yang meliputi evaluasi terhadap hasil penilaian dan tindak lanjut atas rekomendasi perbaikan. Surat Keputusan Kementerian BUMN nomor SK - 16 /S.MBU/2012 menyempurnakan metodologi assessment corporate governance dengan menetapkan indikator/parameter penilaian dan evaluasi.

Penelitian-penelitian terdahulu telah menunjukan manfaat tata kelola perusahaan untuk meningkatkan kinerja perusahaan. Meckling and Jensen (1776) menyatakan dari hasil penelitiannya bahwa perusahaan-perusahaan bisnis yang dimiliki oleh publik merupakan penemuan sosial yang luar biasa. Jutaan individu secara sukarela mempercayakan miliaran dolar, franc, peso, dll. kekayaan pribadi untuk perawatan manajer berdasarkan serangkaian hubungan kontrak yang rumit yang menggambarkan hak dari pihak-pihak yang terlibat. Pertumbuhan 
penggunaan bentuk perusahaan serta pertumbuhan nilai pasar dari perusahaan yang didirikan menunjukkan bahwa setidaknya, hingga saat ini, kreditor dan investor pada umumnya tidak kecewa dengan hasilnya, meskipun biayanya mahal melekat dalam bentuk perusahaan. Tata kelola yang dibangun antara lain dalam bentuk kontrak manajemen ternyata telah memuaskan para pemilik modal. Cahyani (2009) melakukan penelitian yang bertujuan menginvestigasi pengaruh corporate governance perusahaan dengan kinerja perusahaan. Sampel yang digunakan dalam penelitian ini sebanyak 101 sampel yang merupakan pooled data. Hasil pengujian untuk model regresi dengan return on equity sebagai variabel dependennya menunjukkan variabel CGPI secara positif signifikan mempengaruhi kinerja operasi. Al Haddad et. al (2011) telah melakukan penelitian mengenai hubungan antara corporate governance dengan indikator kinerja perusahaan-perusahaan industri di Jordan yang terdaftar pada Amman Stock Exchange (ASE). Hasil penelitian menunjukan adanya hubungan positif antara profitabilitas yang diukur dengan menggunakan EPS dan ROA dan Corporate Governance; hubungan positif antara likuiditas, dividen per saham, dan ukuran perusahaan dengan CG; dan hubungan positif antara CG dengan kinerja perusahaan. Todorovic (2013) menyimpulkan dari hasil penelitiannya adanya hubungan yang sangat jelas dan pengaruh implementasi prinsip-prinsip CG pada kinerja perusahaan. Aggarwal (2013) menyimpulkan dari hasil penelitiannya bahwa tata kelola mempunyai pengaruh yang positif dan signifikan terhadap kinerja keuangan perusahaan. Pillai dan Al Malkawi (2017) meneliti dampak mekanisme internal tata kelola perusahaan (CG) pada kinerja perusahaan di negara-negara GCC. Studi ini menggunakan set panel data tingkat perusahaan dari 349 perusahaan keuangan dan non-keuangan yang terdaftar di bursa saham negara-negara GCC. Hasil penelitian menunjukkan bahwa variabel tata kelola seperti kepemilikan saham pemerintah, jenis audit, ukuran dewan, tanggung jawab sosial perusahaan dan leverage secara signifikan mempengaruhi FP di sebagian besar negara di GCC. Ararat, Black, B. Burcin (2016) menyimpulkan dari hasil penelitianya bahwa terdapat hubungan yang kuat antara tata kelola dengan nilai pasar saham perusahaan perusahaan-perusahaan public di Turki.

Berdasarkan pembahasan tersebut di atas, hipotesa penelitiannya adalah sebagai berikut:

\section{H3: Tata Kelola Perusahaan berpengaruh positif pada kinerja perusahaan.}




\section{Metode Penelitian}

Penelitian ini menggunakan metode penelitian kuantitatip. Pengolahan data dilakukan dengan ordinary least squares (OLS).

Model penelitian kuantitatifnya dirumuskan sebagai berikut:

$\mathrm{Y}=\mathrm{a}+\mathrm{b} 1 \mathrm{X} 1+\mathrm{b} 2 \mathrm{X} 2+\mathrm{b} 3 \mathrm{X} 3+\mu$

Dimana:

$\mathrm{Y}=$ Return on Asset;

$\mathrm{X} 1$ = Remunerasi komisaris;

$\mathrm{X} 2$ = Remunerasi direksi;

X3 = Tata Kelola Perusahaan

Unit analisisnya adalah perusahaan. Populasinya adalah Badan Usaha Milik Negara (BUMN) Bidang Keuangan yang tidak terdaftar pada Bursa Efek Indonesia.

Data penelitian ini merupakan data sekunder. Sampelnya adalah 7 (tujuh) BUMN Bidang Keuangan yang tidak terdaftar pada Bursa Efek Indonesia yaitu PT Pegadaian, Perum Peruri, PT Tugu Pratama, PT Asabri, PT Jamkrindo, PT PNM, dan PT Pengelolaan Aset.

Pengukuran variable penelitian dilakukan sebagai berikut. Proxy dari kinerja perusahaan adalah Return on Asset (ROA). Rumus ROA adalah laba tahun berjalan dibagi dengan aset. Indikator variabel kompensasi komisaris adalah jumlah kompensasi yang diberikan kepada komisaris perusahaan. Pengukurannya adalah dengan mengambil nilai rupiah kompensasi komisaris tahunan yang tercatat di Laporan tahunan perusahaan. Indikator variabel kompensasi direksi adalah jumlah kompensasi yang diberikan kepada direksi perusahaan. Pengukurannya adalah dengan mengambil nilai rupiah kompensasi tahunan direksi yang tercatat di Laporan Keuangan tahunan. Indikator variabel kompensasi direksi adalah jumlah kompensasi yang diberikan kepada direksi perusahaan. Pengukurannya adalah dengan mengambil nilai rupiah kompensasi tahunan direksi yang tercatat di Laporan Tahunan (Annual Report). Pengukuran variable tata kelola perusahaan menggunakan skor assessment GCG berdasarkan Laporan Hasil Assessment GCG oleh assessor eksternal misalnya Badan Pengawasan Keuangan dan Pembangungn (BPKP). 
Pada dasarnya analisis data yang dilakukan akan meliputi uji normalitas data dan uji kausalitas. Uji normalitas data adalah untuk menentukan apakah datanya normal atau tidak sehingga layak diregress dan dijadikan dasar pengambilan simpulan dan keputusan. Selain uji normalitas juga dilakukan uji multikolinearitas, uji heteroskedastisitas, dan uji serial correlation.

Uji regresi terdiri atas uji $\mathrm{F}$ dan uji t. Uji F untuk mengetahui pengaruh secara keseluruhan (simultan) variabel independen terhadap variabel dependennya (dengan indikator signifikansi F). Uji t untuk mengetahui pengaruh parsial satu variabel independen terhadap variabel dependennya (dengan indikator signifikansi t ).

\section{Hasil Penelitian dan Pembahasan}

\section{Hasil Penelitian}

Hasil uji asumsi klasik yang telah dilakukan menunjukan bahwa data penelitian lulus uji asumsi klasik.

Uji regresi yang dilakukan dengan program eviews 9 menunjukan hasil sebagai berikut:

\begin{tabular}{|c|c|c|c|c|}
\hline Variable & & Std. Error & t-Statistic & Prob. \\
\hline $\mathrm{C}$ & $-7.63 E+08$ & $3.29 \mathrm{E}+08$ & -2.320466 & 0.0248 \\
\hline REMUNDIR & -0.003267 & 0.002565 & -1.273364 & 0.2093 \\
\hline REMUNKOM & -0.001975 & 0.005999 & -0.329256 & 0.7435 \\
\hline $\mathrm{CG}$ & 9881175. & 3847269. & 2.568361 & 0.0135 \\
\hline R-squared & 0.166497 & \multicolumn{3}{|c|}{$\begin{array}{l}\text { Mean dependent vi } 46300543 \\
\text { S.D. dependent }\end{array}$} \\
\hline Adjusted R-squared & 0.112138 & var Akaike info & \multicolumn{2}{|l|}{$1.21 \mathrm{E}+08$} \\
\hline S.E. of regression & $1.14 \mathrm{E}+08$ & criterion & \multicolumn{2}{|l|}{40.01676} \\
\hline Sum squared resid & $5.97 \mathrm{E}+17$ & $\begin{array}{c}\text { Schwarz criterion } \\
\text { Hannan-Quinn }\end{array}$ & \multicolumn{2}{|l|}{40.16973} \\
\hline Log likelihood & -996.4191 & criter. & \multicolumn{2}{|l|}{40.07501} \\
\hline F-statistic & 3.062925 & Durbin-Watson sta & \multicolumn{2}{|l|}{0.000467} \\
\hline Prob(F-statistic) & 0.037296 & & & \\
\hline
\end{tabular}

Berdasarkan hasil uji regresi tersebut di atas, adjusted R Squared adalah $11 \%$. Artinya $11 \%$ perubahan dalam Y dapat dijelaskan oleh $11 \%$ perubahan dalam variabel bebas. Adjusted R 
Squared $11 \%$ menunjukan bahwa model penelitian cukup fit.

Uji F menunjukan prob F Statistics $0,03<0,05$. Signifikan. Artinya variabel bebas secara keseluruhan berpengaruh pada variabel terikat.

Hasil uji t1 (uji individual) menunjukan bahwa remunerasi direksi menunjukan t statistik dengan prob $0,2>0,05$. Tidak signifikan. Artinya remunerasi direksi tidak berpengaruh signifikan pada kinerja perusahaan. Dengan demikian hipotesa 1 tidak terbukti.

Hasil uji t2 menunjukan bahwa remunerasi komisaris menunjukan $\mathrm{t}$ statistic dengan prob $0,74>0,05$. Tidak signifikan. Artinya remunerasi komisaris tidak berpengaruh signifikan pada kinerja perusahaan. Dengan demikian hipotesa 2 tidak terbukti.

Hasil uji t3 menunjukan bahwa tata kelola perusahaan menunjukan $t$ statistic dengan prob $0,01<0,05$. Signifikan. Artinya tata kelola perusahaan berpengaruh signifikan pada kinerja perusahaan. Dengan demikian hipotesa 3 terbukti.

\section{Pembahasan}

Variabel remunerasi komisaris ternyata tidak berpengaruh signifikan pada kinerja perusahaan. Malah koefisiennya negative. Kondisi ini menunjukan bahwa meningkatkan remunerasi komisaris BUMN Bidang Keuangan Non Publik belum tentu dapat meningkatkan kinerja perusahaan. Banyak prasyarat lain yang harus ada sebelum remunerasi dapat meningkatkan kinerja komisaris misalnya tingkat pengetahuan dan keahlian komisaris, independensi komisaris, dan kesetiaan komisaris pada perusahaan.

Hasil penelitian ini mendukung hasil penelitian Core, Holthausen, dan Larcker (1998) dan Fernandes (2005). Semua peneliti tersebut menyimpulkan dari hasil penelitianya bahwa tidak ada pengaruh remunerasi komisaris pada kinerja perusahaan. Secara lebih terinci Core, Holthausen, dan Larcker menunjukkan bahwa perusahaan dengan struktur tata kelola yang lebih lemah memiliki masalah agensi yang lebih besar, bahwa CEO di perusahaan dengan masalah keagenan yang lebih besar menerima kompensasi yang lebih besar, dan bahwa perusahaan dengan masalah keagenan yang lebih besar berperforma lebih buruk.

Variabel remunerasi direksi ternyata juga tidak berpengaruh signifikan pada kinerja perusahaan. Malah koefisiennya menjadi negatif juga. Kondisi ini menunjukan bahwa meningkatkan remunerasi direksi BUMN Bidang Keuangan Non Publik belum tentu dapat meningkatkan kinerja perusahaan dalam berbagai proksinya. Walaupun telah diberikan kompensasi yang sesuai 
ternyata direksi belum tentu bertindak untuk kepentingan terbaik negara sebagai pemilik perusahaan. Peningkatan remunerasi ternyata tidak menyebabkan direksi lebih efisien dan efektif dalam mengelola perusahaan. Direksi ternyata tetap mengelola perusahaan pada kecepatan yang sama. Bila remunerasi ditingkatkan malah akan menurunkan kinerja perusahaan.

Kondisi ini mendukung penelitian Doucouliagos, Askary, dan Haman (2006), dan Lindström dan Svensson (2016). Peneliti tersebut menyimpulkan dari hasil penelitiannya bahwa remunerasi direksi tidak berpengaruh pada kinerja perusahaan. Doucouliagos, Askary, dan Haman menyimpulkan bahwa tidak ada hubungan kontemporer antara gaji direktur dan kinerja perusahaan, dan bahkan tidak ada hubungan dengan kinerja tahun sebelumnya. Bukti empiris yang ditemukan Lindström dan Svensson juga menunjukkan bahwa pada tingkat umum, sistem insentif manajemen puncak tidak berpengaruh signifikan terhadap kinerja perusahaan. Lebih jauh Lindström dan Svensson menyatakan bahwa hubungan upah variabel dan kinerja bergantung pada industrinya. Jadi tidak otomatis meningkatkan kinerja perusahaan. Rupelia at. al (2016) juga menyatakan dari hasil penelitiannya bahwa walaupun terdapat hubungan yang signifikan antara remunerasi dewan dengan kinerja, namun tidak pada Return on Asset (ROA), Return on Equity (ROE), dan Earning Per Share (EPS). Namun pada segmen pasar keuangan, ternyata terdapat hubungan yang signifikan secara statistik antara remunerasi dewan dengan hasil dividen di sektor perbankan. Jadi pengaruh remunerasi direksi pada kinerja perusahaan tidak terjadi pada semua proksi dan segmen pasar.

Tata kelola perusahaan berpengaruh positif pada kinerja perusahaan. Dengan demikian usahausaha yang selama ini dilakukan oleh Kementerian BUMN untuk menerapkan tata kelola perusahaan pada BUMN tidak sia-sia. Tata kelola perusahaan yang telah diterapkan ternyata berhasil mendorong kinerja perusahaan. Sesuai dengan tujuannya, tata kelola akan meningkatkan kinerja perusahaan. Kinerja dapat dalam bentuk laba, peningkatan harga saham, maupun citra perusahaan. Permasalahan tata kelola ini akan selalu ada dalam perusahaan selama pemilik dengan pengelola berbeda. Lukviarman (2016) menyimpulkan bahwa masalah tata kelola akan selalu muncul jika terdapat konflik kepentingan di dalam suatu perusahaan. Sementara konflik kepentingan disebabkan oleh adanya ketidakseimbangan kekuatan antara berbagai fihak yang berhubungan. Bila pemilik kurang mengendalikan manajer perusahaan dengan kompensasi dan pengendalian yang memadai maka manajer tidak akan berfikir dan bertindak untuk kepentingan terbaik perusahaan. Karena itulah tata kelola perusahaan diperlukan. 
Kondisi ini mendukung penelitian Al Haddad et. al (2011) dan Todorovic (2013).

Todorovic khususnya menyimpulkan dari hasil penelitiannya adanya hubungan yang sangat jelas dari pengaruh implementasi prinsip-prinsip tata kelola pada kinerja perusahaan. Bila prinsipprinsip tata kelola seperti transparansi dan akuntabilitas diterapkan maka kinerja perusahaan akan meningkat.

\section{E. Simpulan dan Saran}

Penelitian ini bertujuan untuk mempelajari pengaruh remunerasi komisaris, remunerasi direksi, dan tata kelola perusahaan bagi BUMN Bidang Keuangan yang tidak terdaftar di Bursa Efek Indonesia.

Berdasarkan hasil analisis dan pembahasan yang telah dilakukan dengan menggunakan regresi linear berganda, maka diperoleh simpulan sebagai berikut:

1. Remunerasi komisaris tidak berpengaruh signifikan pada kinerja BUMN bidang keuangan non publik. Dengan demikian hipotesa 1 tidak terbukti.

2. Remunerasi direksi tidak berpengaruh signifikan pada kinerja BUMN bidang keuangan non publik. Dengan demikian hipotesa 2 tidak terbukti.

3. Tata kelola perusahaan berpengaruh signifikan pada kinerja BUMN bidang keuangan non publik. Dengan demikian hipotesa 3 terbukti.

Berdasarkan simpulan tersebut di atas maka saran-saran yang dapat diberikan adalah sebagai berikut:

1. BUMN Non Publik agar meningkatkan penerapan tata kelola perusahaan secara berkelanjutan sesuai dengan peraturan yang telah ditetapkan oleh Kementerian BUMN.

2. Untuk mengetahui tingkat pencapaian penerapan GCG agar dilakukan self assessment oleh Perusahaan dan external assessment oleh konsultan yang memiliki keahlian untuk melakukan evaluasi implementasi tata kelola perusahaan.

3. Peningkatan remunerasi direksi agar dilakukan berdasarkan kinerja direksi yang dihitung berdasarkan KPKU dan setelah tata kelola perusahaan mencapai skor baik.

4. Peningkatan remunerasi komisaris agar dilakukan berdasarkan kinerja komisaris yang dihitung berdasarkan KPKU dan setelah tata kelola perusahaan mencapai skor baik. 
5. Agar dilakukan penelitian periodik mengenai pengaruh implementasi tata kelola perusahaan pada kinerja perusahaan.

Peneliti selanjutnya agar melakukan penelitian mengenai pengaruh tata kelola perusahaan pada berbagai proksi dengan menggunakan sampel yang lebih besar.

\section{Daftar Literatur}

\section{Buku}

Komite Nasional Kebijakan Governance. Pedoman Umum Good Corporate Governance Indonesia. KNKG, 2006.

Lukviarman, Niki. Corporate Governance: Menuju Penguatan Konseptual dan Implementasi di Indonesia. The Governance Research Program Fakultas Ekonomi Univeritas Andalas. PT Era Adicitra Intermedia, Solo, 2016.

OECD. Risk Management and Corporate Governance. OECD Publication, 2014.

Office of the Superintendent of Financial Institutions Canada. Guideline of Corporate Governance. 2013.

urnal

Aggarwal, Priyanka. Impact of Corporate Governance on Corporate Financial Performance. IOSR Journal of Business and Management (IOSR-JBM). Volume 13, Issue 3 (Sep. Oct. 2013).

Al-Haddad, W.M.Y., Alzurqan, S.T., Al-Sufy, F.J. The Effect of Corporate Governance On the Performance of Jordanian Industrial Companies: An Empirical Study on Amman Stock Exchange. International Journal of Humanities and Social Sience. Vol. 1 No. 4, April 2011.

Ames, Kevin; Drake, Leigh. Executive remuneration and firm performance: evidence from a panel of mutual organisations. Department of Economics, University of Leicester, Leicester, 2003. 
Ararat, Melsa, Black, Bernard S., Yurtoglu, B. Burcin. The Effect of Corporate Governance on Firm Value and Profitability: TimeSeries Evidence from Turkey. Emerging Market Review, 2016.

Bhagat, S., Bolton, B. Corporate Governance and Firm Performance. Journal of Corporate Finance 14, April 2008.

Brick, Ivan E; Palmon, Oded; Wald, John K. CEO Compensation, Director Compensation, and Firm Performance: Evidence of Cronyism? JCF Special Issue on Corporate Governance, 2005.

Brown, Lawrence D. Caylor, Marcus L. Corporate Governance and Firm Valuation. Journal of Accounting and Public Policy 25 (2006) 409-434.

Bushman, Robert. Chen, Qi. Engel, Ellen. Smith, Abbie. Financial Accounting Information, Organizational Complexity, and Corporate Governance Systems. Journal of Accounting and Economics 37 (2004) 167-201.

Core, John E.; Holthausen, Robert W.; Larcker, David W. Corporate governance, chief executive officer compensation, and firm performance. Journal of Financial Economics, 1998.

Dah, Abdullah; Beyrouti, Nouri; Showeiry, Michel. The Effect of Independent Directors on Firm Value.

Davies, A. Best Practice in Corporate Governance: Building Reputation and Sustainable Success. Gower.

Desoky, Abdelmohsen M. Mousa, Gehan A. Corporate Governance Practices: Transparency and Disclosure - Evidence From The Egyptian Exchange. Journal of Accounting, Finance, and Economics, Vol. 2 No. 1 July 2012 Pp. 49-72.

Doucouliagos, Hristos; Askary, Saeed; Haman, Janto. Directors' remuneration and performance in australian banking. School Working Paper - Economic Series 2006. Faculty of Business and Law, Deakin University.

Fernandes, Nuno. Board Compensation and Firm Performance: The Role of "Independent" Board Members. Universidade Cat'olica Portuguesa, 2005.

Goh, Lisa; Gupta, Aditi. Remuneration of non-executive directors: Evidence from the UK. The British Accounting Review, 2014.

Gupta, Pooja, Sharma, Aarti Mehta. A study of the impact of corporate governance practices on firm performance in Indian and South Korean companie. Elsevier, 2014. 
Hearn, Bruce. The Determinants of Director Remuneration, Executive Tenure, and Individual Executive Disclosure In North African IPO Firms. Research in International Business and Finance, 2013.

Jensen, Michael C., Meckling, William H. Theory of the Firm: Managerial Behavior, Agency Costs and Ownership Structure. Journal of Financial Economics, October, 1976, V. 3, No. 4, pp. 305-360.

Kumar, Praveen; Sivaramakrishnan, K. Who Monitors the Monitor? The Effect of Board Independence on Executive Compensation and Firm Value. University of Houston, 2008.

Lin, Dan; Lin, Lin. The Interplay Between Director Compensation And CEO Compensation. The International Journal of Business and Finance Research, Volume 8, Number 2, 2014.

Lindström, Anna; Svensson, Johanna. Top management compensation and firm performance A matter of context? Department of Business Studies Uppsala University, 2016.

Lo, Huai-Chun; Wu, Ruei-Shian ; Kweh, Qian Long. Do institutional investors reinforce or reduce agency problems? Earnings management and the post-IPO performance. International Review of Financial Analysis, 2016.

Kuo, Chii-Shyan; Yu, Shih-Ti. Remuneration Committee, Board Independence and Top Executive Compensation. J. Risk Financial Manag, 2014.

Magnan, M. St-Onge, S,; Gelinas, P. Director compensation and firm value: A research synthesis. International Journal of Disclosure and Governance Vol. 7, 1, 28-41, 2010.

Melis, Andrea; Gaia, Silvia; Carta, Silvia. Director's Remuneration: A Comparison of Italian and UK Non-Financial Listed Firms' Disclosure. The British Acounting Review, 2014.

Miyienda, Ben; Oirere, Osoro; Miyogo, Julius. The Relationship Between Director Remuneration And Performance Of Firms Listed In The Nairobi Securities Exchange. The International Journal of Social Sciences, 2013.

Murwaningsari, Etty. Hubungan Corporate Governance, Corporate Social Responsibilities dan Corporate Financial Performance Dalam Satu Continuum. Jurnal Akuntansi Dan Keuangan, Vol. 11, NO. 1, Mei 2009: 30-41

Murwaningsari, Etty; Parulian, Tobia. Pengaruh faktor-faktor internal perusahaan terhadap income smoothing. Media Riset Akuntansi, Auditing \& Informasi., Vol. 6, No. 1 April $2006: 75-100$.

Nuswandari, Cahyani. Pengaruh Corporate Governance Perception Index Terhadap Kinerja Perusahaan Pada Perusahaan Yang Terdaftar Di Bursa Efek Jakarta. Jurnal Bisnis dan Ekonomi (JBE), September 2009. 
Ruparelia, Rita; Njuguna, Amos. Relationship between Board Remuneration and Financial Performance in the Kenyan Financial Services Industry. International Journal of Financial Research, 2016.

Scott, William R. Financial Accounting Theory. Pearson Canada Inc., 2015, edisi 7.

Zakaria, Idlan. Performance measures, benchmarks and targets in executive remuneration contracts of UK firms. The British Accounting Review, 2012.

\section{Peraturan}

Kementerian BUMN. Peraturan Menteri Negara Badan Usaha Milik Negara Nomor : PER- 09 /MBU/2012 Tentang Perubahan Atas Peraturan Menteri Negara Badan Usaha Milik Negara Nomor PER-01/MBU/2011 Tentang Penerapan Tata Kelola Perusahaan Yang Baik Pada Badan Usaha Milik Negara.

Kementerian BUMN. Peraturan Menteri Negara Badan Usaha Milik Negara

Nomor : PER - 01 /MBU/2011 Tentang Penerapan Tata Kelola Perusahaan Yang Baik Pada Badan Usaha Milik Negara.

Kementerian BUMN. Keputusan Sekretaris Kementerian Badan Usaha Milik Negara Nomor : SK - 16 /S.MBU/2012 Tentang Indikator/Parameter Penilaian dan Evaluasi Atas Penerapan Tata Kelola Perusahaan Yang Baik (Good Corporate Governance) Pada Badan Usaha Milik Negara.

\section{Website}

www.idx.go.id

www.relianceku.com.

www.bri.ac.id 